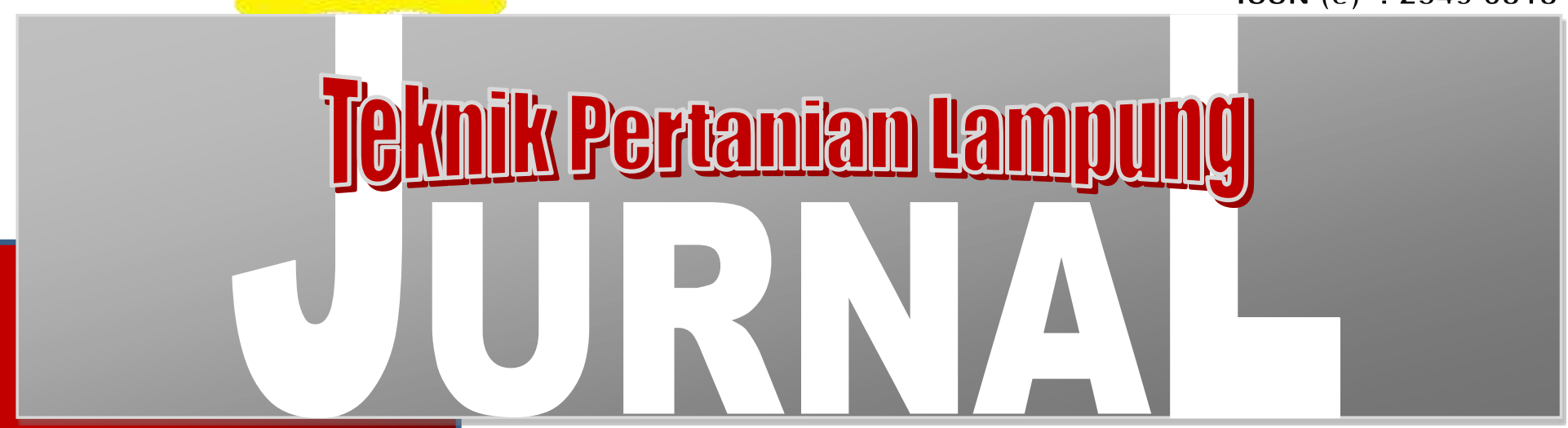

Vol. 7, No. 2, Agustus 2018 


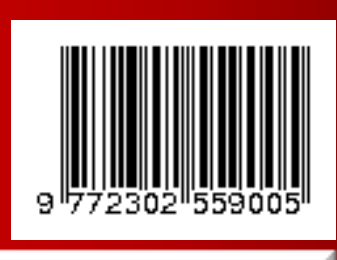


ISSN (p): 2302-559X

ISSN (e): 2549-0818

\section{Geanal TEKNIK PERTANIAN LAMPUNG}

\section{Vol. 7 No. 2, Agustus 2018}

Jurnal Teknik Pertanian (J-TEP) merupakan publikasi ilmiah yang memuat hasil-hasil penelitian, pengembangan, kajian atau gagasan dalam bidang keteknikan pertanian. Lingkup penulisan karya ilmiah dalam jurnal ini antara lain: rekayasa sumber daya air dan lahan, bangunan dan lingkungan pertanian, rekayasa bioproses dan penanganan pasca panen, daya dan alat mesin pertanian, energy terbarukan, dan system kendali dan kecerdasan buatan dalam bidang pertanian. J-TEP terbit sebanyak 3 (tiga) kali dalam satu tahun. Mulai tahun 2018 J-TEP menerbitkan jurnla pada bulan April, Agustus, dan Desember. J-TEP terbuka untuk umum, peneliti, mahasiswa, praktisi, dan pemerhati dalam dunia keteknikan pertanian.

\section{Ketua Editor}

Dr. Ir. Agus Haryanto, M.P

\section{Reviewer}

Prof. Dr. Ir, R.A. Bustomi Rosadi, M.S. (Manajemen Irigasi, Universitas Lampung)

Prof. Dr. Ir. Udin Hasanudin, M.T (Pengelolaan Limbah Agroindustri, Universitas Lampung)

Ir. Mimin Muhaemin, M.Eng., Ph.D (Mekanisasi Pertanian, Universitas Padjajaran)

Dr. Ir. Sugeng Triyono, M.Sc. (Rekayasa Sumberdaya Lahan dan Air, Universitas Lampung)

Dr. Eng Muhammad Makky (Teknik Biosistem, Universitas Andalas)

Dr. Diding Suhandy, S.TP., M.Agr (Spektroskopi, Universitas Lampung)

Dr. Ir. Wiludjeng Trisasiwi, MP (Energi Terbarukan, Universitas Jenderal Soedirman)

Dr. Sri Rahayoe, S.TP, M.P (Pengolahan Pangan, Universitas Gadjah Mada)

\section{Dewan Redaksi}

Ketua : Ahmad Tusi, S.TP, M.Si

Sekretaris : Cicih Sugianti, S.TP, M.Si

Anggota : Dr. Mareli Telaumbanuwa, S.TP, M.Sc

Winda Rahmawati, S.TP, M.Si., M.Sc

Tri Wahyu Saputra, S.T.P. M.Sc.

Jurnal Teknik Pertanian diterbitkan oleh Jurusan Teknik Pertanian, Universitas Lampung.

\section{Alamat Redaksi J-TEP:}

Jurusan Teknik Pertanian, Fakultas Pertanian

Universitas Lampung

Jl. Soemantri Brodjonegoro No.1

Telp. 0721-701609 ext. 846

Website :http://jurnal.fp.unila.ac.id/index.php/JTP

Email :jurnal tep@fp.unila.ac.id dan ae.journal@yahoo.com 


\section{PENGANTAR REDAKSI}

Dengan mengucapkan puji syukur kepada Allah yang Maha Kuasa, Jurnal Teknik Pertanian (JTEP) Volume 7 No 2 Tahun 2018 dapat diterbitkan. Pada edisi kali ini dimuat 7 (tujuh) artikel yang merupakan karya tulis ilmiah dari berbagai bidang kajian dalam dunia Keteknikan Pertanian yang meliputi modifikasi mesin peniris minyak dan analisis kelayakan produksi keripik bayam, kajian media tanam hidroponik dengan media baglog dan arang sekam, penentuan parameter kinetika pada sintesis biodeisel, evaluasi non-destrustif asam lemak bebas dengan spektroskopi, uji kinerja alat pengering jagung, unjuk kerja mesin pemotong padi, dan evaluasi mutu biji melinjo dengan citra digital.

Pada kesempatan kali ini kami menyampaikan ucapan terima kasih yang sebesar-besarnya kepada para penulis atas kontribusinya dalam Jurnal TEP dan kepada para reviewer/penelaah jurnal ini atas peran sertanya dalam meningkatkan mutu karya tulis ilmiah yang diterbitkan dalam edisi ini.

Akhir kata, semoga Jurnal TEP ini dapat bermanfaat bagi masyarakat dan memberikan konstribusi yang berarti bagi pengembangan ilmu pengetahuan dan teknologi, khususnya di bidang keteknikan pertanian.

\section{Redaksi J TEP-Lampung}

ISSN (p): 2302-559X

ISSN (e): 2549-0818 


\section{Gencual TEKNIK PERTANIAN LAMPUNG}

Vol. 7 No. 2, Agustus 2018

Halaman

Daftar isi

Pengantar Redaksi

MODIFIKASI MESIN PENIRIS MINYAK DAN KELAYAKAN FINANSIAL PRODUKSI

KERIPIK BAYAM

Ahmad Thoriq, Totok Herwanto, Drupadi Ciptaningtyas

PENENTUAN NILAI PARAMETER KINETIKA ORDE SATU PADA SINTESIS BIODIESEL DARI MINYAK JELANTAH

Amieria Citra Gita, Agus Haryanto, Tri Wahyu Saputra, Mareli Telaumbanua

EVALUASI NON-DESTRUKTIF KANDUNGAN ASAM LEMAK BEBAS (ALB)

80-87

TANDAN BUAH SEGAR (TBS) KELAPA SAWIT DENGAN METODE NIR

SPEKTROSKOPI

Zaqlul Iqbal, Sam Herodian, Slamet Widodo

UJI KINERJA ALAT PENGERING SILINDER VERTIKAL PADA PROSES

$88-96$

PENGERINGAN JAGUNG (Zea mays ssp.mays)

Made Aditya Putra, Sandi Asmara, Cicih Sugianti, Tamrin

UNJUK KERJA MESIN PEMOTONG PADI (PADDY MOWER) SAAT PEMANENAN

PADI (Oryza Sativa L.) DI LAHAN BASAH

Siti Anisa, Siti Suharyatun, Oktafri, Sandi Asmara

EVALUASI MUTU BIJI MELINJO (Gnetum gnemon L.) MENGGUNAKAN

PENGOLAHAN CITRA DIGITAL

Slamet Widodo dan Muhammad Kalili

KAJIAN MEDIA TANAM HIDROPONIK DARI CAMPURAN BAHAN BAKU LIMBAH BAGLOG DAN ARANG SEKAM

Dyah Isworo, Sugeng Triyono, Agus Haryanto, Iskandar Zulkarnain 


\section{PEDOMAN PENULISAN ARTIKEL BAGI PENULIS}

1) Naskah: Redaksi menerima sumbangan naskah/tulisan ilmiah dalam bahasa Indonesia atau bahasa Inggris, dengan batasan sebagai berikut :

a. Naskah diketik pada kertas ukuran A4 $(210 \mathrm{~mm}$ x $297 \mathrm{~mm})$ dengan 2 spasi dan ukuran huruf Times New Roman 12pt. Jarak tepi kiri, kanan, atas, dan bawah masing-masing $3 \mathrm{~cm}$. Panjang naskah tidak melebihi 20 halaman termasuk abstrak, daftar pustaka, tabel dan gambar. Semua tabel dan gambar ditempatkan terpisah pada bagian akhir naskah (tidak disisipkan dalam naskah) dengan penomoran sesuai dengan yang tertera dalam naskah. Naskah disusun dengan urutan sebagai berikut: Judul; Nama Penulis disertai dengan catatan kaki tentang instansi tempat bekerja; Pendahuluan; Bahan dan Metode; Hasil dan Pembahasan; Kesimpulan dan Saran; Daftar Pustaka; serta Lampiran jika diperlukan. Template penulisan dapat didownload di http://jurnal.fp.unila.ac.id/index.php/JTP

b. Abstrak (Abstract) dalam bahasa Indonesia dan bahasa Inggris, tidak lebih dari 200 kata. Mengandung informasi yang tertuang dalam penulisan dan mudah untuk dipahami. Ringkasan (abstract) harus memuat secara singkat latar belakang, tujuan, metode, serta kesimpulan dan yang merupakan high light hasil penelitian.

c. Pendahuluan: memuat latar belakang masalah yang mendorong dilaksanakannya perekayasaan dan penelitian, sitasi dari temuan-temuan terdahulu yang berkaitan dan relevan, serta tujuan perekayasaan atau penelitian.

d. Bahan dan Metoda: secara jelas menerangkan bahan dan metodologi yang digunakan dalam perekayasaan atau penelitian berikut dengan lokasi dan waktu pelaksanaan, serta analisis statistik yang digunakan. Rujukan diberikan kepada metoda yang spesifik.

e. Hasil dan Pembahasan: Memuat hasil-hasil perekayasaan atau penelitian yang diperoleh dan kaitannya dengan bagaimana hasil tersebut dapat memecahkan masalah serta implikasinya. Persamaan dan perbedaannya dengan hasil perekayasaan atau penelitian terdahulu serta prospek pengembangannya. Hasil dapat disajikan dengan menampilkan gambar, grafik, ataupun tabel.

f. Kesimpulan dan Saran: memuat hal-hal penting dari hasil penelitian dan kontribusinya untuk mengatasi masalah serta saran yang diperlukan untuk arah perekayasaan dan penelitian lebih lanjut.

g. Daftar Pustaka: disusun secara alfabetis menurut penulis, dengan susunan dan format sebagai berikut: Nama penulis didahului nama family/nama terakhir diikuti huruf pertama nama kecil atau nama pertama. Untuk penulis kedua dan seterusnya ditulis kebalikannya. Contoh:

- Kepustakaan dari Jurnal:

Tusi, Ahmad, dan R.A. Bustomi Rosadi. 2009. Aplikasi Irigasi Defisit pada Tanaman Jagung. Jurnal Irigasi. 4(2): 120-130.

- Kepustakaan dari Buku:

Keller, J., and R.D. Bleisner. 1990. Sprinkle and Trickle Irrigation. AVI Publishing Company Inc. New York, USA.

h. Satuan: Satuan harus menggunakan system internasional (SI), contoh : $\mathrm{m}$ (meter), $\mathrm{N}$ (newton), ${ }^{\circ} \mathrm{C}$ (temperature), kW dan W (daya), dll.

2) PenyampaianNaskah:Naskah/karya ilmiah dapat dikirimkan ke alamatdalambentuksoft copyke :

Redaksi J-TEP(JurnalTeknikPertanianUnila)

Jurusan Teknik Pertanian, Fakultas Pertanian

Universitas Lampung

Jl. Sumantri Brodjonegoro No. 1

Telp. 0721-701609 ext. 846

Website : http://jurnal.fp.unila.ac.id/index.php/JTP

Email : jurnal.tep@fp.unila.ac.id atau ae.journal@yahoo.com

3) Selama proses penerimaan karya ilmiah, penelaahan oleh Reviewer, sampai diterimanya makalah untuk diterbitkan dalam jurnal akan dikonfirmasi kepada penulis melalui email.

4) Reviewer berhak melakukan penilaian, koreksi, menambah atau mengurangi isi naskah/tulisan bila dianggap perlu, tanpa mengurangi maksud dan tujuan penulisan. 


\title{
UJI KINERJA ALAT PENGERING SILINDER VERTIKAL PADA PROSES PENGERINGAN JAGUNG (Zea mays ssp. mays)
}

\section{PERFORMANCE TEST OF VERTICAL CYLINDER DRYER IN CORN (Zea mays ssp. mays) DRYING PROCESS}

\author{
Made Aditya Putra ${ }^{1 \bowtie}$, Sandi Asmara ${ }^{1}$, Cicih Sugianti ${ }^{1}$, Tamrin ${ }^{1}$ \\ ${ }^{1)}$ Jurusan Teknik Pertanian, Fakultas Pertanian Universitas Lampung \\ ${ }^{\otimes}$ komuikasi penulis, email : adityamade31@gmail.com \\ DOI: http://dx.doi.org/10.23960/jtep-lv7i1.88-96 \\ Naskah ini diterima pada 16 April 2018; revisi pada 05 Juli 2018; \\ disetujui untuk dipublikasikan pada 17 Agustus 2018
}

\begin{abstract}
Corn (Zea mays ssp. mays) is one of the important crops besides wheat and rice. However the farmers often face the problems such as corn has a high initial water content and unpredictable weather. One alternative tool that can be used for the drying process of corn is vertical cylinder dryer type. The purpose of this research is to determine the characteristic of drying corn and the efficiency of the vertical cylinder dryer during corn drying. The research stages included modification of the dryer with the addition of triangular plate steel on the bottom of chamber to reduce the critical point. The test performed 3 times based on different moisture contents of $29 \% w b$, $27.5 \%$ wb and $26 \% \mathrm{wb}$. The results showed the time used to dry the corn that reached $12-14 \%$ wb of water content was 8 hours, 7 hours, and 6 hours in each different tests. But drying rate for all of performance test almost had the same value of $5 \mathrm{~kg} \mathrm{H} \mathrm{H}_{2} \mathrm{O} /$ hours. Therefore, total efficiency for corn drying counted 23,56\%, 26,90\% and 23,57\% for different performance tests.
\end{abstract}

Keywords : Vertical Cilinder Dryer; Corn; Temperature; Water Content

\begin{abstract}
ABSTRAK
Jagung (Zea mays ssp. mays) merupakan salah satu tanaman pangan dunia yang terpenting selain gandum dan padi. Namun permasalahan yang dihadapi petani yaitu kadar air awal jagung yang tinggi dan cuaca yang tidak mendukung menjadi kendala yang dihadapi dalam proses pengeringan. Salah satu alternatif alat yang dapat digunakan untuk proses pengeringan jagung yaitu alat pengering tipe silinder vertikal. Tujuan dari penelitian adalah untuk mengetahui karakteristik pengeringan jagung dan megetahui efisiensi total alat pengering silinder vertikal selama proses pengeringan. Tahapan penelitian meliputi modifikasi alat dengan penambahan besi plat berbentuk segitiga pada bagian bawah ruang pengering untuk mengurangi titik kritis serta tahap pengujian yang dilakukan 3 kali berdasarkan kadar air 29\% BB, 27,5\% BB dan 26\% BB. Hasil penelitian menunjukan waktu yang digunakan untuk mengeringkan jagung hingga mencapai kadar air $12-14 \%$ pada setiap uji berbeda-beda. Uji kinerja 1 membutuhkan waktu 8 jam, uji kinerja 2 membutuhkan waktu 7 jam dan uji kinerja 3 membutuhkan waktu $6 \mathrm{jam}$. Tetapi laju pengeringan untuk setiap uji kinerja hampir memiliki nilai yang sama sekitar $5 \mathrm{~kg} \mathrm{H}_{2} \mathrm{O} /$ Jam. Sehingga efisiensi total pengeringan pada uji kinerja 1 sebesar $23,56 \%$, uji kinerja 2 sebesar $26,90 \%$ dan uji kinerja 3 sebesar 23,57\%.
\end{abstract}

Kata kunci : Pengering Silinder Vertikal; Jagung; Suhu; Kadar Air. 


\section{PENDAHULUAN}

Jagung (Zea mays ssp. mays) merupakan salah satu tanaman pangan dunia yang terpenting selain gandum dan padi. Selain sebagai sumber karbohidrat jagung juga ditanam sebagai pakan ternak dan dibuat tepung maizena. Jagung memberikan andil bagi pertumbuhan indsutri hulu dan hilir yang kontribusinya pada pertumbuhan ekonomi nasional cukup besar (Susanto, AN dkk., 2005)

Menurut Badan Pusat Statistik (2017) produksi jagung di provinsi Lampung pada tahun 20132017 mengalami fluktuatif. Tahun 2013 produksi jagung provinsi Lampung sebesar 1.760.278 ton dan tahun 2014 mengalami penurunan yaitu sebesar 1.719.386 ton. Pada tahun 2017 produksi jagung provinsi Lampung mengalami peningkatan yang cukup signifikan dari tahun sebelumnya yang mencapai 2.401.393 ton.

Namun permasalahan utama yang dihadapi petani pada musim hujan adalah proses pengeringan jagung hasil panen. Kadar air awal yang tinggi dan cuaca yang tidak mendukung sering menjadi kendala yang sangat sulit diatasi. Petani terkadang terpaksa menjual hasil panen berupa jagung basah atau jagung kering panen sehingga kualitas jagung dianggap rendah dan harga jual menjadi turun. Oleh karena itu pengeringan jagung menjadi penting untuk menentukan pengolahan selanjutnya hingga menjadi jagung yang siap untuk digiling menjadi pakan ternak dan lain-lain. Proses ini diperlukan agar jagung dapat lebih tahan lama terhadap kerusakan yang disebabkan oleh mikroorganisme, seperti halnya kerusakan komponen-komponen kimiawi didalamnya yang dapat mengurangi nilai gizi bahan tersebut (Riansyah, A dkk., 2013).

Salah satu alat pengering buatan untuk mengeringkan jagung adalah pengering silinder vertikal. Alat ini memiliki ruang pengering (plenum) berbentuk silinder dan berdiri secara vertikal alat pengering ini lebih sesuai dipergunakan untuk mengeringkan bahan pangan berbentuk bijian (padi dan jagung). Menurut Fathani, H (2008) alat tersebut menunjukan hasil kinerja yang baik untuk mengeringkan padi dengan menggunakan bahan bakar batu bara dengan waktu pengeringan selama 5 jam dengan kadar air rata-rata 12\%. Penelitian ini menguji alat pengering tipe silinder vertikal dengan menggunakan bahan biji-bijian yang lain yaitu jagung. Proses modifikasi alat pengering dilakukan dengan penambahan plat besi berbentuk segitiga pada bagian bawah alat pengering, hal ini bertujuan untuk mengurangi titik kritis dari alat tersebut yang terletak pada bagian bawah ruang pengering.

Tujuan penelitian adalah untuk mengetahui jumlah bahan bakar yang digunakan selama proses pengeringan, untuk mengetahui penurunan kadar air jagung selama proses pengeringan dan untuk mengetahui efisiensi total alat pengering silinder vertikal selama proses pengeringan.

\section{BAHAN DAN METODE}

\subsection{Alat dan Bahan}

Alat yang digunakan dalam penelitian adalah alat pengering tipe silinder vertikal, timbangan digital, thermometer, alat ukur kadar air (grain moisture tester) dan kipas. Bahan yang digunakan jagung sebanyak $220 \mathrm{Kg}$ dan kayu jati sebagai bahan bakar. Pengujian alat pengering silinder vertikal pada proses pengeringan jagung dilakukan sebanyak 3 kali uji coba dengan jumlah bahan baku yang digunakan pada setiap uji adalah sebesar $220 \mathrm{Kg}$ jagung. Proses pengeringan dilakukan hingga jagung mencapai kadar air $12-14 \%$.

\subsection{Parameter pengamatan}

\section{Suhu Pengeringan}

Pengukuran suhu udara pengering dilakukan menggunakan thermometer yang diletakan pada ruang plenum dan jagung untuk mengetahui perubahan suhu yang terjadi diruang plenum dan jagung dan diamati setiap 30 menit.

\section{Pengukuran Kadar Air}

Sampel diambil dari bahan setiap 30 menit. Sampel yang diambil kemudian dimasukkan ke alat grain moisture tester untuk mengetahui kadar air (\%bb). Sampel diambil 9 titik pada ruang pengering yaitu 3 sampel pada bagian atas , 3 sampel pada bagian tengah, dan 3 sampel pada pada bagian bawah. 


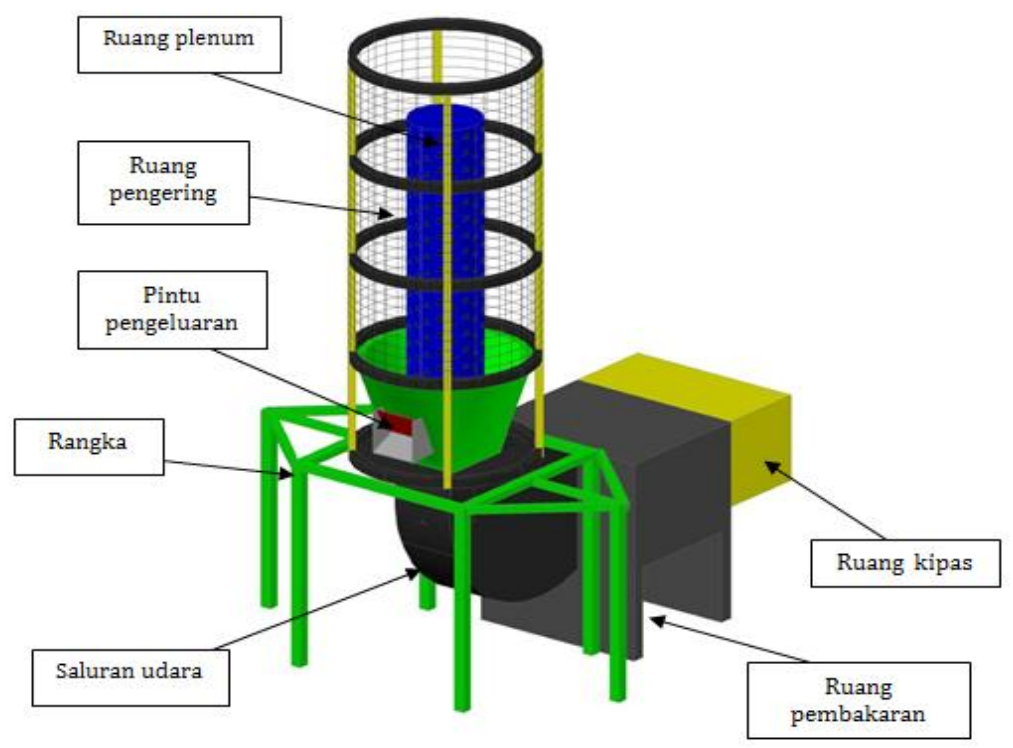

Gambar 1. Desain alat pengering silinder vertikal

\section{Laju Pengeringan}

Laju pengeringan dihitung berdasarkan 2 persamaan Sukatma (1994) dalam Hasmi Fathani (2008) :

$$
\begin{aligned}
& \mathrm{W}_{1}=\frac{E}{t}, \mathrm{dan} \\
& \mathrm{W}_{2}=\frac{M 1-M z}{t}
\end{aligned}
$$

Dimana :

$\mathrm{W}_{1}=$ laju perpindahan air $\left(\mathrm{kg} \mathrm{H}_{2} \mathrm{O} / \mathrm{jam}\right)$

$\mathrm{W} 2$ = laju perpindahan air $(\% \mathrm{bb} / \mathrm{jam})$

$\mathrm{E}=$ Beban uap air $\left(\mathrm{kg} \mathrm{H}_{2} \mathrm{O}\right)$

$\mathrm{M}_{1}=$ kadar air awal (\%)

$\mathrm{M}_{2}=$ kadar air akhir (\%)

$\mathrm{t}$ = waktu pengeringan (jam)

\section{Energi Input}

Energi yang dihasilkan dihitung berdasarkan persamaan :

$$
q=M_{b b} \times q_{b b}+q \text { kipas }
$$

Keterangan :

$\mathrm{M}_{\mathrm{bb}} \quad$ = massa bahan bakar yang digunakan (kg)

$\mathrm{q}_{\mathrm{bb}}=$ nilai panas bahan bakar $(\mathrm{kJ} / \mathrm{kg})$

$\mathrm{q}_{\mathrm{kipas}}=$ Energi listrik yang digunakan untuk menggerakan kipas

\section{Energi Output}

Jumlah energy yang dibutuhkan selama pengeringan dapat dihitung dengan persamaan :

$$
\Sigma \mathrm{Q}=\mathrm{Q}_{1}+\mathrm{Q}_{2}
$$

Dimana :

$\Sigma Q=$ jumlah panas yang digunakan untuk memanaskan dan menguapkan air bahan (kJ)

$\mathrm{Q}_{1}=$ jumlah panas yang digunakan untuk menguapkan air bahan (kJ)

$\mathrm{Q}_{2}=$ Jumlah panas yang digunakan untuk memanaskan bahan (kJ)

$$
\mathrm{Q}_{1}={\mathrm{E} \times \mathrm{H}_{1 \mathrm{~b}}}
$$

Keterangan :

$\mathrm{Q}_{1}=$ energy untuk menguapkan air bahan (kJ)

$\mathrm{E}$ = beban uap air $\left(\mathrm{kg} \mathrm{H}_{2} \mathrm{O}\right)$

$\mathrm{H}_{1 \mathrm{~b}}=$ panas laten $(\mathrm{kJ} / \mathrm{Kg})$

Keterangan :

$$
\mathrm{H}_{1 \mathrm{~b}}=2501-2,361 \mathrm{~T}
$$

$\mathrm{H}_{1 \mathrm{~b}}=$ panas laten $(\mathrm{kJ})$

$\mathrm{T}=$ Suhu bahan $\left({ }^{\circ} \mathrm{C}\right)$

Keterangan :

$$
\mathrm{Q}_{2}=\mathrm{m} \times \mathrm{C}_{\mathrm{p}} \mathrm{x} \Delta \mathrm{T}
$$

Q2 = Energi untuk menguapkan air bahan (kJ)

$\mathrm{m}=$ massa bahan yang dikeringkan $(\mathrm{kg})$

$\mathrm{C}_{\mathrm{p}}=$ panas jenis bahan yang dikeringkan $(\mathrm{kJ} / \mathrm{kg}$ ${ }^{\circ} \mathrm{C}$ )

$\Delta \mathrm{T}=$ Perbedaan suhu bahan dan suhu lingkungan $\left({ }^{\circ} \mathrm{C}\right)$

\section{Efisiensi Pengeringan}

Efisiensi pengeringan dihitung berdasarkan perbandingan antara jumlah energy untuk 
menguapkan air bahan dengan energi yang dihasilkan bahan bakar kayu jati dengan menggunakan persamaan (Tamrin, 2013) :

$$
\text { Eff }=\frac{\sum \varepsilon}{q} \times 100 \%
$$

Keterangan :

$$
\begin{array}{ll}
\text { Eff } & =\text { efisiensi pemanasan, } \% \\
\Sigma Q & =\text { energi output }, \mathrm{kJ} \\
\mathrm{q} & =\text { energi input }, \mathrm{kJ}
\end{array}
$$

\section{HASIL DAN PEMBAHASAN}

\subsection{Sebaran Suhu Pengeringan (Ruang plenum)}

Data sebaran suhu pada ruang plenum diambil pada 3 titik yaitu titik bawah, titik tengah dan titik atas. Perbedaan titik letak pengambilan sampel suhu pada ruang plenum bermaksud untuk mengetahui penyebaran suhu pada tiap titik apakah ada perbedaan suhu yang berbeda antara titik bawah, titik tengah dan titik atas. Berikut hasil pengukuran suhu pada ruang plenum yang disajikan pada Gambar 2, Gambar 3, dan Gambar 4.

Pada Gambar 2 menunjukan sebaran suhu pada ruang plenum dengan pengukuran setiap 30 menit suhu yang dihasilkan tidak konstan. Sebaran suhu pada bagian tengah dan atas ruang plenum memiliki nilai sebaran suhu tertinggi pada setiap menit pengukuran, suhu tertinggi yang dihasilkan di uji kinerja 1 yaitu mencapai 96으 dan 95으. Sedangkan sebaran suhu terendah pada setiap pengukuran terjadi pada bagian bawah ruang plenum dengan suhu tertinggi mencapai $81^{\circ} \mathrm{C}$. Pengukuran suhu plenum pada menit ke 0 dan menit ke 30 mengalami

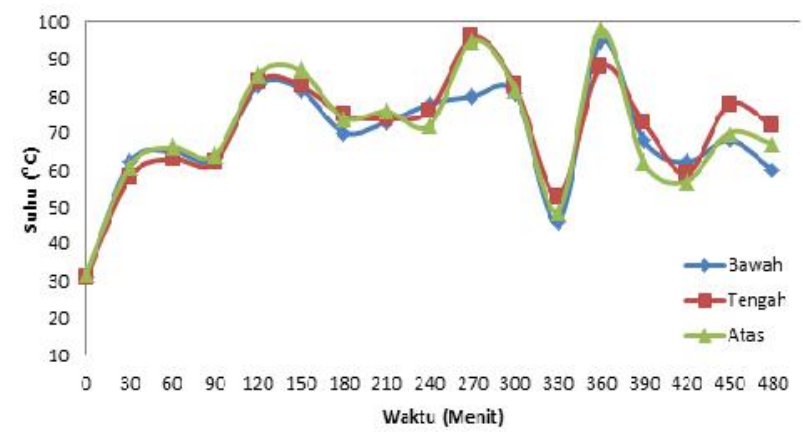

Gambar 2. Sebaran suhu pengeringan pada ruang plenum uji kinerja 1

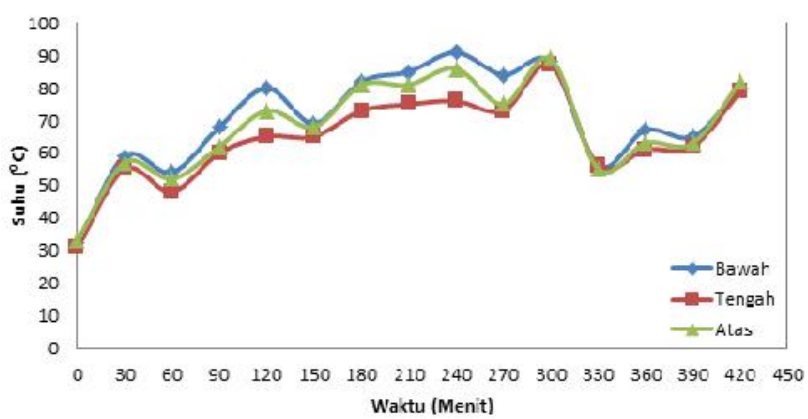

Gambar 3. Sebaran suhu pengeringan pada ruang plenum uji kinerja 2

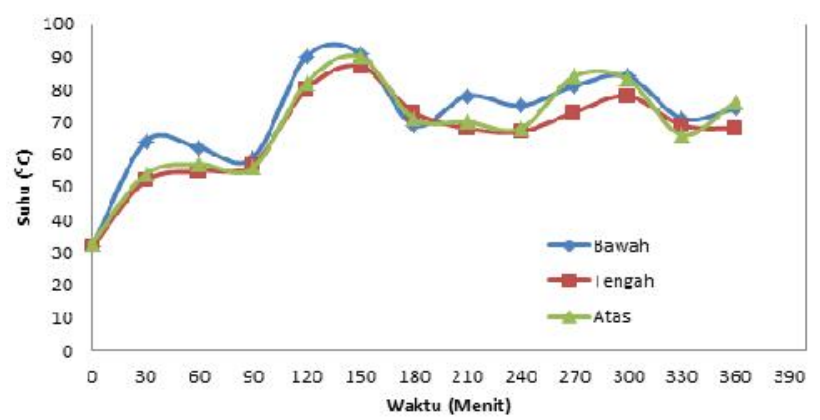

Gambar 4. Sebaran suhu pengeringan pada ruang plenum uji kinerja 3 
peningkatan yaitu dari suhu $31^{\circ} \mathrm{C}$ menjadi $62^{\circ} \mathrm{C}$. Hal itu dikarenakan pada rentang waktu itu bahan bakar mulai dinyalakan sehingga suhu yang ada pada ruang plenum akan meningkat. Pengukuran suhu ruang plenum pada menit ke 120 sampai menit 300 mengalami fluktuatif yang dipengaruhi suhu pada ruang pembakaran yang tidak konstan. Namun pengukuran menit ke 300 dan pada menit ke 330 mengalami penurunan suhu dari $81^{\circ} \mathrm{C}$ menjadi $46^{\circ} \mathrm{C}$ disetiap titik pengukuran bawah, tengah dan atas. Hal ini dikarenakan memasukan bahan bakar pada menit tersebut terlambat sehingga berpengaruh terhadap suhu yang ada diruang plenum.

Pada Gambar 3 menunjukan sebaran suhu pada ruang plenum dengan pengukuran setiap 30 menit suhu yang dihasilkan tidak konstan. Sebaran suhu pada bagian tengah dan atas ruang plenum memiliki nilai sebaran suhu tertinggi pada setiap menit pengukuran, suhu tertinggi yang dihasilkan di uji kinerja 1 yaitu mencapai 96으 dan 95ㄷ. Sedangkan sebaran suhu terendah pada setiap pengukuran terjadi pada bagian bawah ruang plenum dengan suhu tertinggi mencapai $81^{\circ} \mathrm{C}$. Pengukuran suhu plenum pada menit ke 0 dan menit ke 30 mengalami peningkatan yaitu dari suhu $31^{\circ} \mathrm{C}$ menjadi $62^{\circ} \mathrm{C}$. Hal itu dikarenakan pada rentang waktu itu bahan bakar mulai dinyalakan sehingga suhu yang ada pada ruang plenum akan meningkat. Pada menit ke 120 sampai menit 300 mengalami fluktuatif yang dipengaruhi suhu pada ruang pembakaran yang tidak konstan. Namun, pada pengukuran menit ke 300 dan pada menit ke 330 mengalami penurunan suhu dari $81^{\circ} \mathrm{C}$ menjadi $46^{\circ} \mathrm{C}$ disetiap titik pengukuran bawah, tengah dan atas. Hal ini dikarenakan memasukan bahan bakar pada menit tersebut terlambat sehingga berpengaruh terhadap suhu yang ada diruang plenum.

Pada Gambar 4 sebaran suhu tertinggi terjadi pada bagian bawah ruang plenum suhu tertinggi yang dihasilkan selama proses pengeringan mencapai $91^{\circ} \mathrm{C}$ pada pengukuran menit ke 150 . Sebaran suhu pada bagian tengah dan atas ruang plenum memiliki sebaran suhu yang realtif sama pada setiap pengukuran, pada bagian tengah suhu tertinggi mencapai $87^{\circ} \mathrm{C}$ pada menit ke 150 dan bagian atas suhu tertinggi mencapai $90^{\circ} \mathrm{C}$ pada menit ke 150. Peningkatan suhu pada ruang plenum terjadi pada pengukuran menit ke 90 sampai menit ke 150 pada ke 3 bagian ruang plenum dengan peningkatan suhu 59으 mencapai $90^{\circ} \mathrm{C}$. Untuk pengukuran suhu yang konstan yaitu pada menit 180 sampai dengan menit ke 330 dengan penurunan suhu antara $5^{\circ} \mathrm{C}-10^{\circ} \mathrm{C}$. Suhu ruang plenum tertinggi yang dihasilkan pada uji kinerja 3 yaitu pada menit ke 150 dengan suhu rata-rata pada bagian bawah, tengah dan atas sebesar $89^{\circ} \mathrm{C}$.

\subsection{Kadar Air}

Penurunan kadar air merupakan faktor terpenting keberhasilan dari setiap alat pengering yang akan di uji. Sampel diambil pada 3 bagian yaitu A (depan), B (Samping kanan), C (Belakang). Pada setiap bagian masing-masing diambil 3 titip sampel yaitu titik 1 (Bawah), titik 2 (Tengah), dan titik 3 (Atas). Dengan demikian pengambilan sampel bahan pada ruang pengering berjumlah 9 sampel. Berikut hasil pengukuran kadar air yang disajikan pada Gambar 5, Gambar 6, dan Gambar 7.

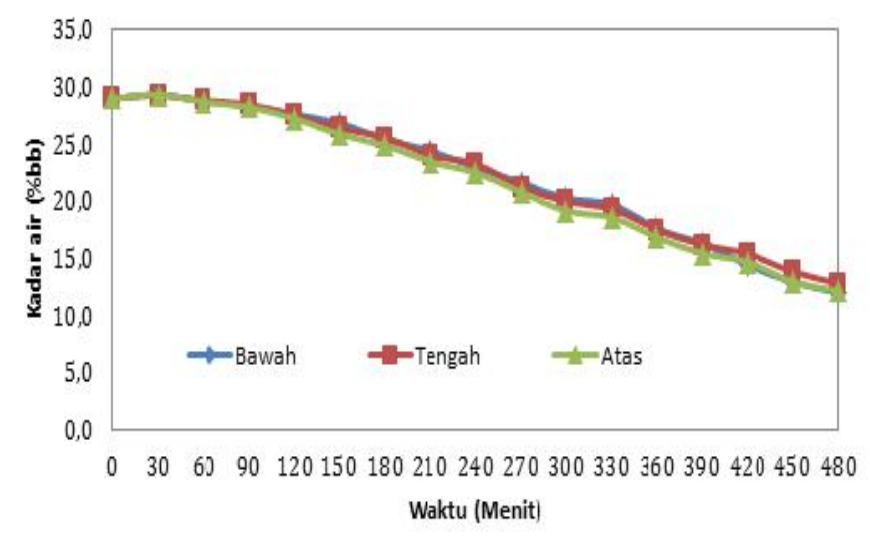

Gambar 5. Grafik penurunan kadar air bahan uji kinerja 1 
Gambar 5 pada uji kinerja 1 dengan kadar air awal jagung sebesar $29 \%$ diperlukan waktu pengeringan selama 480 menit (8 jam). Pada 30 menit awal kadar air jagung mengalami peningkatan sebesar $0,2-0,5 \%$ pada setiap titik pengambilan, hal ini dikarenakan jagung mengalami proses pelepasan air dari bahan menuju lingkungan yang disebabkan perbedaan antara suhu bahan dan suhu lingkungan yang berpengaruh terhadap meningkatnya kadar air jagung yang sedang diuji. Rentang nilai penurunan kadar air berkisar antara 0,2 - 1,2\% setiap kurun waktu 30 menit, sehingga didapatkan kadar air akhir rata-rata pada uji kinerja 1 sebesar $12 \%$.

Gambar 6 pada uji kinerja 2 dengan kadar air awal jagung sebesar 27,5 \% diperlukan waktu pengeringan selama 420 menit ( 7 jam). Pada 30 menit awal kadar air jagung mengalami peningkatan sebesar $0,3 \%$ pada setiap titik sampel pengambilan, hal ini dikarenakan jagung mengalami proses pelepasan air dari bahan menuju lingkungan yang disebabkan perbedaan antara suhu bahan dan suhu lingkungan yang berpengaruh terhadap meningkatnya kadar air jagung yang sedang diuji. Rentang nilai penurunan kadar air berkisar antara 0,5 - 2\% setiap kurun waktu 30 menit sehingga didapatkan kadar air akhir rata-rata jaung pada uji kinerja 2 sebesar $12 \%$.

Gambar 7 pada uji kinerja 3 dengan kadar air awal jagung sebesar $26 \%$ diperlukan waktu pengeringan selama 360 menit (6 jam). Pada 30 menit awal kadar air jagung mengalami peningkatan sebesar 0,3-0,5\% pada setiap titik pengambilan, hal ini dikarenakan jagung mengalami proses pelepasan air dari bahan menuju lingkungan yang disebabkan perbedaan antara suhu bahan dan suhu lingkungan yang berpengaruh terhadap meningkatnya kadar air jagung yang sedang diuji. Penurunan kadar air pada bagian bawah, tengah dan atas relatif sama yaitu $0,4 \%-0,9 \%$ pada setiap 30 menit. Kadar air dalam bahan pangan menentukan daya awet bahan pangan. Makin rendah kadar air, makin lambat pertumbuhan mikroba dan bahan pangan dapat bertahan lama untuk disimpan Winarno (2002) dalam Atmaka, W (2010)

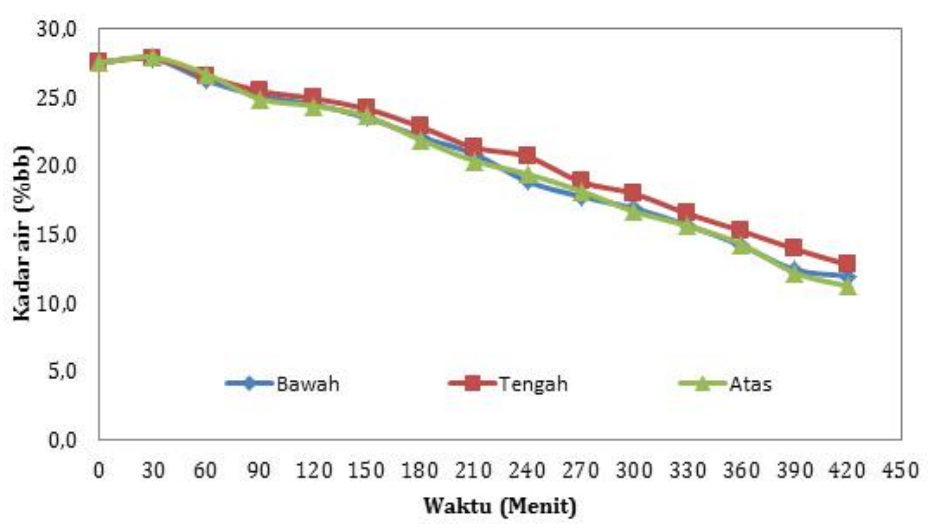

Gambar 6. Grafik penurunan kadar air bahan uji kinerja 2

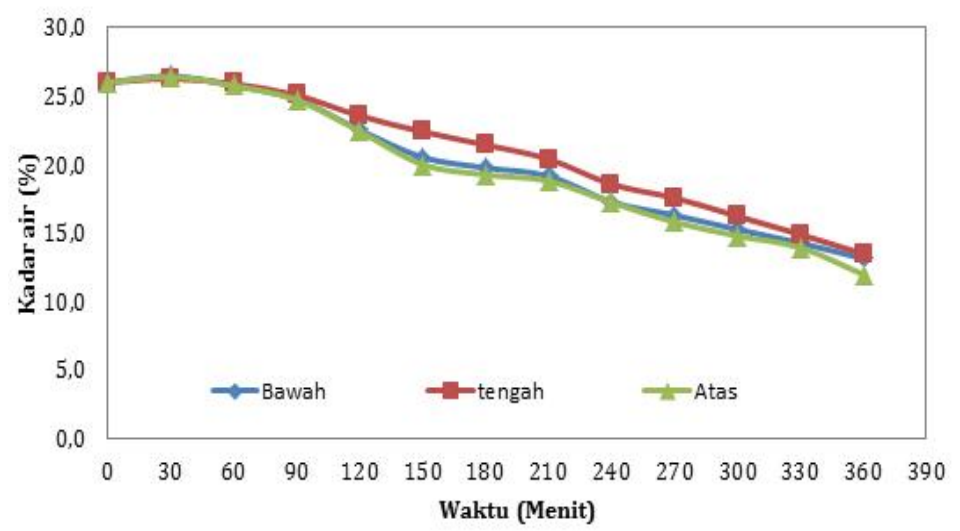

Gambar 7. Grafik penurunan kadar air bahan uji kinerja 3 
Penurunan kadar air bahan jagung pada penelitian ini menggunakan 3 kali uji kinerja yaitu uji kinerja 1, uji kinerja 2 dan uji kinerja 3. Pada uji kinerja 1 waktu pengeringan berlangsung selama 8 jam untuk mencapai kadar air rata-rata $12,30 \%$ sedangkan pada uji kinerja 2 waktu pengeringan berlangsung selama 7 jam untuk mencapai kadar air rata-rata 11,8\%. Pada uji kinerja 3 waktu pengeringan berlangsung selama 6 jam untuk mencapai kadar air rata-rata $12,33 \%$.

Penurunan kadar air paling cepat terjadi pada uji kinerja 3 dalam waktu 6 jam hal ini dikarenakan kadar air awal bahan jagung yang digunakan yaitu sebesar $26 \%$ kemudian kadar air rata-rata yang didapat yaitu sebesar 12,33\% .Sedangkan untuk penurunan kadar air yang lebih lama terjadi pada uji kinerja 1 dengan estimasi waktu 8 jam dikarenakan kadar air awal jagung yang digunakan sebesar $29 \%$ kemudian kadar air rata-rata yang didapat selama proses pengeringan yaitu sebesar $12,30 \%$. Kadar air terendah pada penelitian ini didapatkan pada uji kinerja 2 dengan kadar rata-rata mencapai 11,8 \%. Menurut Yanda, R.J dkk (2014) laju penurunan kadar air merupakan banyaknya kandungan air yang keluar dari bahan persatuan waktu. Semakin tinggi penguapan kadar air bahan maka akan semakin tinggi tingkat penurunan kadar air.

Pada Gambar 5-7 grafik penurunan kadar air setiap uji memiliki rentan nilai yang sama yaitu sebesar 1-2\% setiap 60 menit akan tetapi kadar air awal bahan jagung yang digunakan pada setiap uji memiliki nilai berbeda. Pada uji kinerja 1 kadar air awal jagung sebesar $29 \%$, uji kinerja $27,5 \%$ dan uji kinerja 3 sebesar $26 \%$, sehingga waktu yang diperlukan untuk proses pengeringan pada uji kinerja 1 memiliki waku yang lebih panjang dibandingkan pada uji kinerja 2 dan 3 yang memiliki kadar air jagung yang lebih rendah. Menurut penelitian Sari, I.N (2014) laju penurunan kadar air meningkat tajam pada awal pengeringan sampai mendekati kadar air $20 \%$, tetapi selanjutnya laju penurunan kadar air menurun secara perlahan-lahan.

Parameter yang mempengaruhi proses pengeringan ini adalah suhu pengering, $\mathrm{RH}$ pengering, kadar air awal bahan, kadar air akhir bahan, dan kecepatan udara pengering. Berdasarkan data suhu pengering saat pengujian didapatkan nilai suhu tertinggi mencapai $93^{\circ} \mathrm{C}$ dan suhu terendah $62^{\circ} \mathrm{C}$. Hal ini sesuai dengan penelitian Nastiti, M.A dkk (2014) Bahwa nilai kadar air yang tinggi disebabkan oleh suhu pengeringan yang rendah karena proses penguapan yang relatife rendah sedangkan semakin tinggi suhu udara pengeringan, semakin besar panas yang dibawa udara sehingga semakin banyak jumlah air yang diuapkan dari permukaan bahan yang dikeringkan.

\subsection{Waktu Pengeringan}

Lama pengeringan diukur pada saat kayu jati dan kipas pendorong udara sudah dihidupkan. Waktu pengeringan yang dibutuhkan untuk mengeringkan jagung hingga mencapai kadar air yang diingikan pada uji kinerja 1 adalah 8 jam, uji kinerja 2 adalah 7 jam dan uji kinerja 3 adalah 6 jam.

\subsection{Laju Pengeringan}

Laju pengeringan merupakan perpindahan air dari bahan menuju udara atau lingkungan. Menurut Tamrin (2013) faktor-faktor yang mempengaruhi dalam laju pengeringan adalah kadar air, luas permukaan, suhu, kecepatan udara, kelembaban udara (RH), tekanan atmosfer dan waktu. Rata-rata laju pengeringan jagung selama proses pengeringan yang memakai bahan bakar kayu jati pada uji kinerja 1 sebesar $5,23 \mathrm{~kg} \mathrm{H}_{2} \mathrm{O} /$ jam atau 2,08 \%BB/Jam. Laju pengeringan pada uji kinerja 2 sebesar 5,54 $\mathrm{kg} \mathrm{H}_{2} \mathrm{O} /$ jam atau 2,21 $\% \mathrm{BB} / J a m$ dan laju pengeringan pada uji kinerja 3 sebesar 5,53 $\mathrm{kg} \mathrm{H}_{2} 0 / \mathrm{Jam}$ atau 2,19\%BB/Jam.

\subsection{Analisis Efisiensi}

\subsubsection{Energi Input}

Berdasarkan hasil pengukuran energi yang dihasilkan dengan mengukur energi listrik yang dihasilkan untuk menggerakan pendorong udara (Kipas) pada uji kinerja 1 dengan daya 40 watt dan waktu pengeringan 8 jam didapatkan nilai sebesar $1.152 \mathrm{~kJ}$ dan nilai panas yang dihasilkan kayu jati (Q kayu jati) sebesar 19.660 kJ serta massa kayu jati yang digunakan sebesar 22,4 kg maka nilai energi yang dihasilkan pada uji kinerja 1 sebesar $441.540,49 \mathrm{~kJ}$. 
Pada uji kinerja 2 dengan waktu pengeringan 7 jam daya kipas 40 watt nilai panas kayu jati ( $Q$ kayu jati) sebesar $19.660 \mathrm{~kJ}$ serta massa kayu jati yang digunakan 18,2 kg maka energi yang dihasilkan pada uji kinerja 2 sebesar 358.823,64 $\mathrm{kJ}$. Pada uji kinerja 3 dengan waktu pengeringan 6 jam daya kipas 40 watt nilai panas kayu jati $(Q$ Kayu jati) sebesar 19.660 kJ serta massa kayu jati yang digunakan 17,7 kg maka energi yang dihasilkan pada uji kinerja 3 sebesar 348.849,54 $\mathrm{kJ}$.

Menurut Napitupulu, FH dkk (2012) waktu pengeringan untuk mengeringkan biji kakao lebih cepat dengan menggunakan bahan bakar kayu bakar dari pada menggunakan bahan bakar kerosin. Hal ini dipengaruhi oleh proses pembakaran yang lebih cepat dengan menggunakan kayu bakar dari pada menggunakan bahan bakar kerosin.

\subsubsection{Energi Output}

Energi yang digunakan untuk menguapkan air dan untuk memanaskan bahan pada uji kinerja 1 dengan Cp jagung $1,112 \mathrm{~kJ} / \mathrm{kg}^{\circ} \mathrm{C}$ dan panas laten $2.398,07 \mathrm{~kJ} / \mathrm{kg}$ yaitu sebesar $104.027,88 \mathrm{~kJ}$. Energi yang digunakan pada uji kinerja 2 dengan $\mathrm{Cp}$ jagung $1,112 \mathrm{~kJ} / \mathrm{kg}^{\circ} \mathrm{C}$ dan panas laten $2.398,76 \mathrm{~kJ} / \mathrm{kg}$ yaitu sebesar $3.400 \mathrm{~kJ}$. Energi yang digunakan pada uji kinerja 3 dengan $\mathrm{Cp}$ jagung $1,112 \mathrm{~kJ} / \mathrm{kg}^{\circ} \mathrm{C}$ dan panas laten $2.407,26$ $\mathrm{kJ} / \mathrm{kg}$ yaitu sebesar 82.246,16 kJ.

\subsubsection{Efisiensi Pengeringan}

Efisiensi pengeringan yang merupakan jumlah energi yang digunakan untuk menguapkan air dan memanaskan bahan dibagi dengan energi yang dihasilkan selama proses pengeringan. Berdasarkan dari hasil perhitungan yang didapat dapat diketahui efisiensi pengeringan dengan alat pengering tipe silinder vertikal dengan bahan bakar menggunakan kayu jati pada uji kinerja 1 sebesar $23,56 \%$ pada uji kinerja 2 sebesar 26,90 $\%$ dan pada uji kinerja 3 sebesar $23,57 \%$.

\section{KESIMPULAN DAN SARAN}

\subsection{Kesimpulan}

1. Pengujian alat pengering tipe silinder vertikal dengan menggunakan bahan jagung sebanyak 220 kg pada uji kinerja 1 dengan kadar air awal jagung sebesar $29 \%$ serta waktu pengeringan selama 8 jam didapatkan kadar air rata-rata jagung sebesar $12,3 \%$. Pada uji kinerja 2 dengan kadar air awal jagung sebesar $27,5 \%$ serta waktu pengeringan selama 7 jam didapatkan kadar air rata-rata jagung sebesar 12,0\%. Pada uji kinerja 3 dengan kadar air awal jagung sebesar $26 \%$ serta waktu pengeringan selama 7 jam didapatkan kadar air rata-rata jagung sebesar $12,9 \%$.

2. Bahan bakar yang digunakan pada penelitian ini adalah kayu jati uji kinerja 1 menggunakan bahan bakar kayu jati sebanyak 22,4 kg, uji kinerja 2 menggunakan bahan bakar kayu jati sebanyak 18,2 kg dan uji kinerja 3 menggunakan bahan bakar kayu jati sebanyak $17,7 \mathrm{~kg}$.

3. Efisiensi alat pengering tipe silinder vertikal dengan menggunakan kayu jati sebagai bahan bakar pada uji kinerja 1 adalah sebesar 23,56\%, uji kinerja 2 adalah sebesar 26,90\% dan uji kinerja 3 adalah sebesar $23,57 \%$.

\subsection{Saran}

Berdasarkan hasil penelitian, penulis menyampaikan saran sebagai berikut:

1. Perlu adanya konsistensi waktu dalam penambahan bahan bakar kayu jati saat proses pengeringan berlangsung hal ini bertujuan agar suhu yang dihasilkan pada saat proses pengeringan berlangsung tetap stabil.

2. Perlu dilakukan penelitian lanjutan menggunakan bahan bakar yang berbeda untuk mengetahui jenis bahan bakar yang terbaik pada alat pengering silinder vertikal untuk proses pengeringan jagung.

\section{DAFTAR PUSTAKA}

Atmaka, W. Sigit, B. 2010. Kajian Karakteristik Fisikokimia Tepung Instan Beberapa Varietas Jagung (Zea mays L). Jurnal Teknologi Hasil Pertanian. 3 (1) 13-20.

BPS. 2013. Produksi Jagung Provinsi Lampung. Diakses tanggal 28 Maret 2018.

Fathani, H. 2008. Rancang Bangun Alat Pengering Gabah Tipe Silinder Vertikal. Skripsi. Bandar Lampung. Jurusan Teknik 
Pertanian Fakultas Pertanian Universitas Lampung.

Napitupulu, F.H., Tua, P.M. 2012. Perancangan dan Pengujian Alat Pengering Kakao Dengan Tipe Cabinet Dryer Untuk Kapasitas 7,5 Kg Per-Siklus. Jurnal Dinamis. 2 (10) 8-18.

Nastiti, M.A., Hendrawan, Y., Yulianingsih, R. 2014. Pengaruh Konsentrasi Natrium Metabisulfit (Na2S205) dan Suhu Pengeringan Terhadap Karakteristik Tepung Ampas Tahu. Jurnal Bioproses Komoditas Tropis. 2 (2) 100-106.

Riansyah, A., Supriadi, A., Nopianti, R. 2013. Pengaruh Perbedaan Suhu dan Waktu Pengeringan Terhadap Karakteristik Ikan Asin Sepat Siam (Trichogaster pectoralis) Dengan Menggunakan Oven. Skripsi. Fakultas Pertanian Universitas Sriwijaya. 2 (1) 53-68.
Sari, I.N., Warji., dan Novita, D.D. 2014. Uji Kinerja Alat Pengering Hybrid Tipe Rak Pada Pengeringan Chip Pisang Kepok. Jurnal Teknik Pertanian Lampung. 3 (1) 5968.

Susanto, A.N., Sirappa, M.P. 2005. Prospek dan Strategi Pengembangan Jagung Untuk Mendukung Ketahanan Pangan di Maluku. Jurnal Litbang Pertanian. 24 (2) 70-79.

Tamrin. 2013. Buku Ajar Teknik Pengeringan. Bandar lampung. Jurusan Teknik Pertanian Fakultas Pertanian Universitas Lampung. 12-13.

Yanda, R.J., Syah, H., Agustina, R. 2014. Uji Kinerja Pengering Surya dengan Kincir Angin Savonius untuk Pengeringan Ubi Kayu (Manihot esculenta). Jurnal Rona Teknik Pertanian. 7 (2) 100-111. 